\title{
Urdimento
}

Revista de Estudos em Artes Cênicas

E-ISSN: 2358.6958

\section{Desejo de convívio: uma carta é uma visita}

\author{
Luciana Cezário Milagres de Melo
}

\section{Para citar este artigo:}

MELO, Luciana Cezário Milagres de. Desejo de convívio: uma carta é uma visita. Urdimento, Florianópolis, v. 3, n. 39, nov./dez. 2020.

DOI: http:/dx.doi.org/10.5965/14145731033920200109

Este artigo passou pelo Plagiarism Detection Software | iThenticate 


\title{
Desejo de convívio: uma carta é uma visita'
}

Luciana Cezário Milagres de Melo²

\begin{abstract}
Resumo
Este artigo propõe o compartilhamento da pesquisa de Mestrado "Mergulho no Escuro: O teatro é [no] encontro com o outro no mundo", realizada na Escola de Belas Artes da Universidade Federal de Minas Gerais, na linha de pesquisa Artes da Cena. Nesta pesquisa foi proposta uma residência artística em três unidades prisionais femininas tendo como referência práticas e concepções contemporâneas em teatro. O trabalho foi realizado a partir da ideia de que a escrita e o compartilhamento de cartas pessoais poderia ser mote para um acontecimento teatral. A investigação revelou a potência das artes da cena na proposição de encontros de intimidades junto às mulheres presas.
\end{abstract}

Palavras-Chave: Cartas. Convivialidade. Mulheres presas. Teatralidades liminares.

\section{The need to get on with others: A letter is a visit}

\begin{abstract}
This article derives from the Master's thesis Diving in the Dark: The Theater is [in] the Encounter with the Other in the World, held at the Fine Arts School of the Minas Gerais Federal University in Performing Arts. For this research, an artistic residency based on contemporary theater practices took place in three female prisons. This work derived from the premise that writing and sharing personal letters could serve as the epigraph for a theatrical event. The work revealed the power of the performing arts in workshops with female prisoners.
\end{abstract}

Keywords: Female prisoners. Letters. Conviviality. Preliminary theatricalities.

1 Este artigo é resultante em sua quase integridade de minha dissertação de mestrado defendida na Universidade Federal de Minas Gerais, na Escola de Belas Artes, em 2017, referenciada na bibliografia final deste texto.

2 Profa. do Departamento de Arte, Design e Tecnologia do CEFET/MG. Mestra em Artes pelo Programa de Pós Graduação em Artes (Escola de Belas Artes/UFMG). lucianacmmelo@gmail.com 
Deseo de convivencia: una carta es una visita

\section{Resumen}

Este artículo sí propone compartir la investigación de Maestría "Buceo en el oscuro: el teatro es [en el] encuentro con el otro en el mundo", realizada en la Escuela de las Bellas Artes de la Universidad Federal de Minas Gerais, en la línea de investigación en las Artes Escénicas. En esa investigación fue propuesta una residencia artística en tres cárceles de mujeres, teniendo como referencia, prácticas y concepciones contemporáneas en teatro. El trabajo fue realizado partiendo de la idea de que escribir y el acto de compartir cartas personales, podría ser motivo para vivir un acontecimiento teatral. La investigación ha revelado la potencia de las artes escénicas, en la propuesta de encuentros íntimos con las mujeres presas.

Palabras Clave: Cartas. Convivialidad. Mujeres presas. Teatralidades liminales. 
Busco, nesse artigo, compartilhar o processo de minha pesquisa de mestrado, realizada no Programa de Pós-Graduação em Artes da Escola de Belas Artes da Universidade Federal de Minas Gerais, orientada pela professora Dra. Marina Marcondes Machado. Nessa investigação, propus uma residência artística em três unidades prisionais femininas, com duração de 4 dias consecutivos em cada, totalizando 12 encontros. Cada encontro foi construído a partir de concepções contemporâneas do campo das Artes da Cena; por minha trajetória artística e pelo contexto da pesquisa, levando em conta as espacialidades prisionais e tendo como foco as mulheres presas e seus mundos de vida ${ }^{3}$. Cheguei assim à criação de um programa que propôs a escrita e o compartilhamento de cartas pessoais ficcionais e autobiográficas - como mote para um acontecimento teatral.

Inicialmente o trabalho aconteceria em 4 unidades prisionais, mas em uma delas tive muitas dificuldades no contato com a direção4. A pesquisa, realizada entre 2015 e 2017, aconteceu no Complexo Penitenciário de Ponte Nova (Ponte Nova, MG); no Presídio Feminino José Abranches Gonçalves (Ribeirão das Neves, MG) e no Complexo Penitenciário Feminino Estevão Pinto - PIEP (Belo Horizonte, $M G)$.

Previ a duração de duas horas para cada encontro, no entanto, os tempos foram sempre autorregulados pela vida mesma, seja no funcionamento da unidade, seja no modo de ser das mulheres presas. O número de participantes também era variável a cada encontro e mantive a possibilidade de que fossem nos dias que quisessem e pudessem5. Pudemos ficar, quase sempre, sozinhas no espaço onde o trabalho acontecia, sem mediação de agentes penitenciários.

Trabalhei com a ideia de que a performance pode ser um modo

\footnotetext{
${ }^{3}$ A noção de "mundos de vida" é empregada, neste trabalho, a partir do diálogo com a fenomenologia, um dos aportes teóricos desta pesquisa. Segundo Joel Martins (1992, p. 52) na abordagem fenomenológica, não é "possível compreender o homem e o mundo de outra forma, senão a partir da sua 'facticidade'. Isso quer dizer, segundo a maneira de ser-no-mundo, sujeito às contingências como um ser que é lançado ao mundo, mundo que o precede a alcança, no qual o homem, ao ver-se como tal, precisa lutar para encontrar-se".

${ }^{4}$ Irei discorrer, posteriormente, sobre o diálogo, junto ao sistema prisional, para viabilizar a realização do trabalho.

${ }^{5} \mathrm{O}$ número de participantes variou tanto que houve encontros com 05 participantes e encontros com 28 mulheres presentes. A tabela completa com a participação a cada dia, em cada unidade prisional, pode ser conferida na dissertação. (Melo, 2017 P. 67).
} 
contemporâneo de se fazer teatro: propus esse modo às mulheres presas, que corresponderam ao convite. Interessava-me a noção de performance como antidisciplina (Carlson, 2010) e seu transbordamento em confluência com outros campos, principalmente a antropologia.

Busquei construir um trabalho que não coubesse em fronteiras rígidas, que transbordasse, que acontecesse em uma margem, borda, límen difícil de definir. Como disse Kantor (apud Caballero, 2011, p. 108): "de tal forma que a pergunta 'Isto já é arte?' ou 'Isto ainda não é vida?' não tem mais importância para mim". Investiguei modos de fazer teatro nos interstícios da vida, a partir da noção de teatralidades liminares, desenvolvida pela pesquisadora Ileana Dieguez Caballero (2011), em diálogo com o antropólogo e teórico da performance social Victor Turner.

Caballero (2011) propõe esse conceito para pensarmos certos fenômenos que, a partir do século XX, parecem se situar entre o acontecimento artístico e a realidade social - eventos que não cabem nas taxonomias tradicionalmente estabelecidas no campo teatral e se situam em um entrecruzamento entre a arte e a vida

Outra concepção fundante da pesquisa foi a noção de teatro como convívio, construída em diálogo com o pensamento de Jorge Dubatti (2007). Para este autor a convivialidade é um princípio ancestral do teatro $^{6}$ e compreende estar com os outros, mas também consigo mesmo; ato dialético que envolve escutar os outros para se escutar, encontrar-se com o outro e, através desse encontro, retornar a si:

Importa o diálogo das presenças, a conversação: o reconhecimento do outro e de si mesmo, afetar e deixar-se afetar no encontro, gerando uma suspensão da solidão e do isolamento. Chamaremos a este componente do convívio a companhia - do baixo latim compania, que etimologicamente remete a cum (com) e panis (pão): os que se reúnem são companheiros, quer dizer, "os que compartem o pão." (Dubatti, 2007, p. 47).

${ }^{6}$ Em tempos de isolamento social é também relevante o pensamento de Jorge Dubatti sobre tecnovívio, disponível em artigos na internet e vídeos no Youtube. 
O convívio é visto então como uma interrupção da solidão e do isolamento e o pão que se compartilha é a criação: poíesis de artistas e de espectadores - todos criadores, todos dão e recebem o pão nesse espaço de intimidade onde é possível construir sentidos sobre si e sobre o mundo.

Tendo como referência a noção de acontecimento convivial (Dubatti, 2007) trabalhei com a ideia de que o teatro é no encontro com o outro no mundo e tentei ir além ao buscar viver o que a pesquisadora das Artes da Cena Carminda André (2008) nomeia "encontro de intimidades".

Este trabalho se constituiu a partir das noções de performance e seus transbordamentos e fecundas relações com outros campos, numa zona liminar; busquei viver um acontecimento poético e espectatorial fundado na convivialidade. Vivi, junto às mulheres, uma partilha de sensibilidades; partilhamos nossa humanidade. A escrita e compartilhamento de cartas foi mote para que esse compartilhamento acontecesse.

Inicialmente, escolhi me apresentar às mulheres participantes através de uma performance, baseada na escrita de uma carta ao meu pai, vinte e dois anos após sua morte ${ }^{7}$. Essa performance matizou a construção de um roteiro, com duração de quatro dias, tendo como cerne a escrita e o compartilhamento de cartas pessoais biográficas e ficcionais. No processo de criação da proposta, o filme Central do Brasil (1998) foi incorporado, inicialmente, pelo fato de privilegiar o contexto das cartas e pela figura da personagem Dora, interpretada por Fernanda Montenegro - em cuja função, ser escrevedora de cartas, vislumbrei potencial performativo. Pouco a pouco, o filme revelou outros sentidos subjacentes à pesquisa, como buscarei evidenciar.

Apresento, a seguir, uma breve sinopse de cada encontro da residência artística:

10 dia - Central do Brasil: apresentei-me, de modo breve, às mulheres participantes e assistimos ao filme Central do Brasil, de Walter Salles (1998). O 
filme foi a inspiração para os demais encontros, permeados pela escrita e compartilhamento de cartas pessoais: mote para a performance, que aconteceu no encontro entre as mulheres participantes e eu, pesquisadora-performer.

2o dia - Performance Travessia: apresentei-me às mulheres presas de forma performativa e através de um trabalho artístico que já desenvolvia, reelaborado para acontecer no contexto da pesquisa. Trata-se de um trabalho artístico criado a partir de fotos e de uma carta que escrevi para meu pai, falecido quando eu tinha sete anos. A carta e a certidão de óbito foram lidas e comentadas, como "motes dramatúrgicos", de forma a evidenciar aspectos autobiográficos.

3o dia - Potência da escrita de cartas: retomei o filme Central do Brasil e a carta escrita a meu pai, para propor a escrita de cartas. As cartas podiam ser para pessoas reais ou imaginadas; presentes, ausentes ou inexistentes em suas vidas. Propus também, tal qual a personagem Dora, ser uma "escrevedora de cartas". As mulheres interessadas ditaram suas cartas para que eu escrevesse. Ofereci envelope, selo e postagem nos Correios.

4o dia - Despedida: propus o compartilhamento das cartas escritas como um modo de performar e uma conversa final sobre o encontro. Combinamos tentar trocar cartas, modo de continuar convivendo, mesmo com as distâncias.

Todos os encontros foram registrados na busca por descrições densas do campo de pesquisa, nos diários de bordo, etnografia da experiência vivida.

\section{Por que e como fazer teatro com mulheres presas?}

Desde a decisão de fazer o campo da pesquisa em unidades prisionais, um questionamento surgiu e permaneceu no decorrer do processo, com diferentes nuances: por que fazer teatro contemporâneo com mulheres presas? Por que e como propor experiências artísticas em presídios? Essa complexa questão colocada por mim mesma, pela minha orientadora e por diversas pessoas às quais comunicava a pesquisa, tem, no mínimo, dois desdobramentos.

O primeiro diz respeito à especificidade do campo. A resposta à pergunta "por 
que mulheres presas?" está amparada em minha biografia e no meu desejo de uma pesquisa plena de mundo (Hissa, 2013). Meus trabalhos em toda minha trajetória estão ligados a questões sociais - no âmbito profissional, artístico e acadêmico. Concordo com Cássio Hissa quando diz que "a escolha da temática de pesquisa está envolvida por uma trama histórica na qual o sujeito está plenamente envolvido." (Hissa, 2013, p. 100).

O segundo desdobramento tem relação com o ponto de vista das mulheres presas. O que "ganhariam" ao participar do trabalho? Que contribuições eu iria oferecer? Esses são questionamentos importantes, do ponto de vista ético. Como fazer para que o trabalho não fosse significativo somente para mim? Como pesquisadora eu não tinha controle sobre os sentidos construídos por cada mulher ao participar da residência artística, mas o cuidado ético com a forma como os encontros iriam ressoar foi um princípio orientador deste trabalho.

Em conversas de orientação, por exemplo, surgiu o receio de que o trabalho causasse dor às mulheres; pensar sobre si, no âmbito da privação da liberdade, poderia provocar tristeza e outras emoções às mulheres participantes a partir de lembranças, ausências e invisibilidades. Através de reportagens na mídia e do contato com a bibliografia da área (Queiroz, 2015), soube da recorrência de casos de abandono (pela família e pelos companheiros) e perda do contato ou guarda de filhos.

A primeira ida a campo confirmou a validade daqueles receios: as mulheres presas vivem uma situação de vida muito delicada. Assim, busquei conduzir o trabalho apurando ao máximo minha sensibilidade e escuta, mantendo a proposta aberta. Além disso, a participação na pesquisa foi por adesão voluntária e as participantes poderiam deixar de participar a qualquer momento que desejassem.

Intentei viver, junto às mulheres, uma partilha de sensibilidades; partilhar nossa humanidade. A escrita e o compartilhamento de cartas foram um mote para que essa partilha acontecesse. Parti do princípio de que o teatro é [no] encontro com o outro no mundo; escolhi uma forma de fazer teatro que propõe convívio e relação. Num espaço onde ocorre um aniquilamento do "eu" (Goffman, 2010), onde 
podemos falar sobre um processo de "coisificação" ou desumanização, propus a experiência artística como algo que potencializa as singularidades, cria afetos e possibilita processos de humanização.

Minha noção de pesquisa em teatro também é um dizer político, em busca de reflexividade, criticidade, transformação de mundos, meu e do outro, no "entre", na interseção. A partir de escolhas éticas e estéticas busco dialogar propositivamente com a realidade social: o teatro como tática de guerra, como diria Carminda André (2008); teatro para provocar antiestruturas, como propõe Marina Machado (2015).

\section{As unidades prisionais: "Diz pra minha irmã não me abandonar aqui, porque aqui é escuro"8}

As presas estavam no pátio. Estavam sentadas no fundo do pátio, de frente para a parede, de costas para as celas. Eu estava concentrada. Vi que a diretora de segurança falou para as presas se organizarem e virem em ordem (acho que era a ordem das celas). Quando dei por mim, levantei a cabeça, olhei para o lado e levei um susto: uma mulher, com roupa "de guerra", toda preta, colete a prova de balas, uma espécie de capacete na cabeça, o rosto tampado, só os olhos de fora. Ao lado dela um pastor alemão enorme, furioso. Ela o segurava pela coleira. As presas vinham, de acordo com a cela, andando em fila, numa linha marcada no concreto, no chão. Era uma coreografia meticulosamente ensaiada. Ela gritava: CELA 1! As presas vinham nessa fila, a cabeça baixa, os braços para trás, silêncio. Ela gritava coisas como: RÁPIDO! É SÉRIO! Às vezes se incomodava com algo, como quando gritou para uma presa: PODE TIRAR A CANETA DO CABELO. O cachorro, quase sempre, latia ferozmente, a boca espumava. Elas entravam e a diretora de segurança e as duas agentes trancavam a cela. Fiquei hipnotizada pela cena, sem ar, a boca seca, com medo daquele cachorro e daquela mulher. O horror, o horror. (Diário de Bordo, 12 ago. 2016).

O processo para obter autorização para a realização da pesquisa foi um dos desafios enfrentados, provocando angústias em alguns momentos: seja porque a demora para se conseguir a autorização significou uma grande dificuldade de lidar com os prazos firmados pela universidade; seja pela

\footnotetext{
${ }^{8}$ Frase escrita na carta ditada por uma mulher presa.
} 
possibilidade, evidente, de que a pesquisa não fosse autorizada.

Ainda no início desse diálogo junto à Subsecretaria de Administração Prisional (SUAPI)9 recebi uma ligação de uma funcionária que queria tirar dúvidas. Ela fez algumas perguntas e apresentou-me dificuldades e impedimentos para a realização da proposta ${ }^{10}$. Ela também comentou que eu não sabia como era, que eu estaria "em contato com presas de todo tipo, que tem as mais calmas, as nervosas, as debochadas, as que não vão querer participar”. Antes de finalizar a ligação, falou que o trabalho era pioneiro e que "ninguém quer fazer trabalhos com as presidiárias" - afirmação que me marcou muito.

A ligação telefônica evidenciou dificuldades em relação à lógica de funcionamento das unidades prisionais. Segundo Vicente Concílio (2008, p. 147)

entrar em um presídio e propor um processo teatral é, em muitos aspectos, o avesso do tipo de trabalho que é feito naquele espaço, preocupado que está seu corpo funcional em manter o equilíbrio da instituição mediante muita vigilância, medo e punição.

Pude, a cada encontro, compreender essas palavras, assim como perceber as possibilidades subjacentes a uma proposta em Artes da Cena naqueles espaços.

Segundo Goffman (2010, p. 24), ao dar entrada em uma instituição total, a pessoa possui certas concepções sobre si, possíveis graças a "algumas disposições sociais estáveis no seu mundo doméstico". Ao ser privada de liberdade, imediatamente vê-se despida do apoio dado por tais disposições. A esse processo o autor nomeia "mortificação":

começa uma série de rebaixamentos, degradações, humilhações e profanações do eu. O seu eu é sistematicamente, embora muitas vezes não intencionalmente, mortificado. Começa a passar por algumas mudanças radicais em sua carreira moral, uma carreira composta pelas progressivas mudanças que ocorrem nas crenças que têm a seu respeito e a respeito dos outros que são significativos para ele. (Goffman, 2010, p.

9 A SUAPI foi extinta e atualmente o órgão responsável pelas unidades prisionais é o Departamento Penitenciário de Minas Gerais.

${ }^{10}$ Contudo, posteriormente, consegui realizar a residência artística e entrar com os materiais conforme havia proposto. 
24, grifos do autor).

A primeira mutilação do eu é a separação entre o "mundo de dentro" e o "mundo de fora". Goffman, um importante autor para os estudos da performance, considera que o comportamento social é, de alguma maneira, "performado" (Carlson, 2010). Em suas pesquisas, criou uma metáfora baseada em práticas teatrais para estudar as interações sociais, estabelecendo uma relação entre papéis sociais e personagens teatrais.

Já no contexto dos espaços prisionais - e de outras instituições totais Goffman (2010) relaciona a mutilação do eu a um "despojamento do papel". Segundo suas ideias, na "vida civil" - ou seja, fora da instituição - o indivíduo vive uma multiplicidade de papéis, alternados durante sua rotina diária. Na instituição total, pelo contrário, a continuidade dos papéis é perturbada, "pois a separação entre o internado e o mundo mais amplo dura o tempo todo e pode continuar por vários anos" (Goffman, 2010, p. 24). No caso desta pesquisa, a barreira que separa as mulheres presas do mundo externo à prisão provoca a perda de alguns de seus papéis sociais.

Goffman (2010l p. 48) afirma que "as instituições totais são fatais para o eu civil do internado". Em uma das unidades, impressionou-me a postura de Marta ${ }^{11}$, que parecia preservar um olhar firme, de frente, sem subserviência. Vi quando conversava com uma agente pela grade. Perguntava algo, parecia solicitar um atendimento. A agente lhe explicava de modo apressado, em poucas palavras. Ela insistia. A agente falou rindo: "preso parece que não entende". A resposta veio antes que a frase fosse concluída: "preso não, Marta Silva Ferreira". Ela parecia tentar recuperar para si um estatuto de sujeito, de pessoa, de alguém que existe fora de uma categoria.

Os processos de mortificação são, muitas vezes, fundamentados em explicações racionalistas, tais como as questões de segurança em unidades prisionais. Contudo,

\footnotetext{
${ }^{11}$ Todos os nomes são fictícios.
} 
as várias justificativas para a mortificação do eu são muito frequentemente simples racionalizações, criadas por esforços para controlar a vida diária de grande número de pessoas em espaço restrito e com pouco gasto de recursos. Além disso, as mutilações do eu ocorrem [...] mesmo quando o internado está cooperando e a direção tem interesses ideais pelo seu bem-estar. (Goffman, 2010, p. 48).

A partir das ideias deste autor, podemos perceber os processos de mortificação do eu a que as mulheres presas estão submetidas, evidenciados, sobretudo, nas barreiras que as separam do mundo externo e no "despojamento do papel”.

Goffman (2010, p. 69) afirma que, "quase sempre, muitas instituições totais parecem funcionar apenas como depósitos de internados”, mas mantêm um discurso público de "organizações racionais, conscientemente planejadas como máquinas eficientes para atingir determinadas finalidades oficialmente confessadas e aprovadas”. Goffman (2010, p. 70) comenta que esse é um trabalho com pessoas e que "como material de trabalho, as pessoas podem adquirir características de objetos inanimados.”

Sobre a distância que os funcionários devem manter dos "internos", para não desenvolverem laços de afeição ou camaradagem, Goffman (2010, p. 75) é irônico ao proferir: "existe sempre o perigo de que o internado pareça humano". O autor aponta ainda que as instituições totais tendem a criar o que poderíamos nomear como uma "teoria da natureza humana": pressupostos sobre o caráter dos seres humanos que justificariam os modos de funcionamento da instituição:

como uma parte implícita da perspectiva institucional, essa teoria racionaliza a atividade, dá meios sutis para manter a distância social com relação aos internados e uma interpretação estereotipada deles, bem como para justificar o tratamento que lhes é imposto. (Goffman, 2010, p. 80).

Um dos elementos mais marcantes no espaço prisional são os procedimentos disciplinares que instauram modos de ser, estar e se relacionar pautados na lógica de submissão, coerção e punição. Esses dispositivos de controle afetam diretamente as corporalidades das presas. 
Ao apresentar um panorama histórico das transformações nos modos de coerção e punição ao longo do tempo, Foucault (2010, p. 133) ressalta como, a partir do século XVII, as disciplinas se tornaram uma forma de dominação:

esses métodos que permitem o controle minucioso das operações do corpo, que realizam a sujeição constante de suas forças e thes impõem uma relação de docilidade-utilidade, são o que podemos chamar as "disciplinas".

Trata-se de exercer "uma coerção sem folga" sobre o corpo, ininterrupta. Um trabalho que visa ao domínio sobre o corpo dos outros, para que atuem como se quer. Um poder cuja missão maior é adestrar. Em Ribeirão das Neves, as presas caminhavam pelo espaço com as mãos para trás e de cabeça baixa, às vezes com os braços algemados. Elas eram encaminhadas para a residência artística e, ao entrar na sala, mesmo sem algema, conservavam as mãos para trás. Também parecia algo natural formarem uma fila na porta da sala quando o encontro terminava: assim se organizavam para ir embora. Vi presas em estado de espera para serem encaminhadas para algum lugar: elas ficam com os braços para trás, de costas, com o rosto na parede. Também vi as mulheres me aguardando no pátio em um dos encontros. Estavam sentadas em um dos cantos, próximas ao muro, de costas.

Nas unidades prisionais, os tempos de espera são vividos cotidianamente: espera por cartas, espera por dias melhores, por um alvará de saída, por uma visita, para estar em liberdade, para reencontrar os filhos. Em Ponte Nova, fiquei sabendo, pelas participantes, que terça e quinta são os dias em que chegam as cartas na unidade - ou como dizem, o dia em que "pagam" cartas. E elas esperam... Leila contou que toda terça fica à espera. A carta não vem. Ela espera até quinta, pensa: "Quinta vai chegar". Mas não chega também. Ela então se concentra na próxima terça. E assim vai vivendo, aguentando, esperando; "até choram quando chega”. A espera pelas cartas parece, de alguma forma, demarcar o tempo de espera na prisão. Ajuda a passar os dias na espera-esperança de uma carta que seja também um afago. 


\section{A Residência artística: Encontros de intimidade}

Para pensar o conceito de residência artística nesta pesquisa, é particularmente importante a noção de deslocamento, entendida como a ida a espaços e contextos estrangeiros: "a desterritorialização como condição básica da criação" (Packer, 2014, p. 28). A partir da busca por experimentar o mundo por meio da pesquisa, Packer fala sobre uma geopolítica da mobilidade nas artes que acontece para além dos eixos tradicionais; as residências entendidas como modo de

desenvolver relações de reciprocidade, que permitam que todo lugar possa operar como centro, lugar de chegada, acolhimento e partida, "reterritorialização." (Packer, 2014, p. 32).

Fundamentam-se, assim, no deslocamento de artistas para outros contextos culturais onde se vive o "desafio do estar deslocado e viver junto" (Moraes, 2009, p. 31): a criação artística aliada a trocas no encontro com o outro, mas também consigo mesmo - "o seu 'eu-outro', aquele que você só encontraria a partir da experimentação, pesquisa e reflexão" (Vasconcelos, 2014, p. 21). Constituem zonas temporárias de criação compartilhada. Espaços-tempos onde existem possibilidades específicas de sociabilidade e alteridade, na experiência de ser estrangeira e criar, em convivência.

Ao refletir sobre o contexto brasileiro, marcado por fortes contradições no direito à terra e à moradia, Packer (2014) nos convida a relativizar a própria noção de residência. Essa provocação do autor reverberou em mim no questionamento sobre a condição de vida das mulheres que participaram da proposta: as unidades prisionais podem ser pensadas como residências? Do ponto de vista das mulheres presas me parece que não. E o que elas mais desejam é o retorno às suas casas. Algumas se angustiam por não ter onde morar.

Nesta pesquisa, compreendi e propus a residência artística como um modo de criação na fronteira entre arte e vida, a partir do meu deslocamento para um tempo-espaço específico. Pensei a residência artística como um modo de habitar as unidades prisionais femininas. No encontro com as mulheres presas e os 
contextos prisionais - incluindo as espacialidades e temporalidades - vivemos processos de criação. A partir dessa ideia, encontro ressonância em Joel Martins que cita Heidegger: "habitamos aquilo que construímos" (Heidegger apud Martins, 1992, p.88) e afirma:

para os gregos essa construção, o fazer e o habitar o que foi construído, constitui a poiesis. O termo envolve, necessariamente, uma criação, um pensar, um construir onde o poeta habita. (Martins, 1992, p. 88).

Maria Teresa Louro, artista entrevistada por Marcos Moraes (2009, p. 70), afirma algo parecido: "a residência não é o lugar, é o lugar novo que se instala na pessoa [...] a residência é, na minha opinião, hoje ocupar um outro espaço em si e no próprio trabalho."

Como apresentado anteriormente, a residência artística aconteceu durante quatro dias consecutivos, em três unidades prisionais femininas. O trabalho começou com um filme, passou pela minha apresentação e o desvelamento de questões íntimas e autobiográficas e seguiu rumo à passagem de foco para as mulheres presas: suas histórias e condições de vida, momento de poder dizer de si, como quiser, se quiser. Parece-me que, se por um lado, performar a carta escrita a meu pai nos tornou cúmplices, por outro, o filme abriu portas para a relação se construir, ao trazer à tona a temática das cartas e da ausência de um pai desejado e nos comover com o encontro entre Dora e Josué.

Vi, em cada unidade, nossa relação mudar, dia a dia. Sentia que ficávamos mais próximas e elas menos desconfiadas. Aos poucos iam deixando de me chamar de Dona ou de Senhora e passavam a me chamar pelo nome, ou simplesmente Lu.

Apresento, a seguir, meu encontro com os mundos de vida das mulheres participantes a partir das ressonâncias da residência artística.

\section{Momento 1: Central do Brasil}

Como dito anteriormente, o primeiro dia da residência artística foi dedicado a assistirmos ao filme Central do Brasil, lançado em 1998 e dirigido por Walter 
Salles, com roteiro de João Emanuel Carneiro e Marcos Bernstein. Marcos Strecker (2010, p. 11), jornalista e crítico de arte, analisou a produção cinematográfica de Walter Salles e conceituou seu trabalho como "cinema humanista, da ética e da delicadeza" . Afirmou, ainda, que nas produções do diretor, questões sociais e individuais estão presentes, acontecem de modo paralelo. Ao assistir Central do Brasil é possível compreender e agregar sentidos às palavras de Strecker. Relação potencializada quando a experiência foi compartilhada com mulheres presas.

Nas três unidades nos emocionamos com o encontro entre Dora, escrevedora de cartas na Estação Central do Brasil, e Josué, menino que sonha conhecer o pai idealizado. Sentia que o filme nos tocava a todas e, de alguma forma, nos aproximava: deixava vir à tona nossa condição humana, nos uníamos nas tristezas da ausência, das saudades e lembranças, da presença da morte, na nossa própria solidão. Ao final da exibição havia um silêncio emocionado. Confidenciei, a cada vez: também tenho vontade de chorar com esse filme. Elas me olhavam de modo menos sério e desconfiado. Algumas sorriam. Agradeciam. Central do Brasil parecia inaugurar um novo espaço que, pouco a pouco, fomos construindo.

\section{Momento 2: Performance Travessia}

A performance Travessia foi apresentada como um trabalho relacionado às cartas, à ausência do pai e à saudade que fica na fotografia, assim como no filme Central do Brasil, que inaugurou o trabalho e permeou os demais dias. Essa performance foi construída tendo como ponto de partida uma carta que escrevi ao meu pai, a partir de uma foto antiga sua, tirada ainda antes de eu nascer. Apresentei-me às mulheres participantes a partir do luto e da criação artística. A ação tem duração aproximada de 15 minutos e aconteceu do seguinte modo: mostrei a foto de meu pai 'antes d'eu nascer' que originou a escrita da carta. Coloquei no chão a foto, o atestado de óbito, a carta e um aparelho mp3 com fone de ouvido. Li a certidão de óbito do meu pai. Li a carta que escrevi para ele, 22 anos após sua morte. Ouvi uma música através de um fone de ouvido. Inicialmente 
somente eu podia ouvi-la. Dancei. A música ouvida no fone de ouvido é Travessia, de Milton Nascimento e Fernando Brant.

A foto de meu pai provocava gargalhadas de algumas: que brega aquele homem cabeludo e barbudo trajando roupas tão fora de moda! O atestado de óbito causava certa comoção. Silêncio. Ao ler a data da morte - 1992 - ouvi, num suspiro: "eu nem tinha nascido"; "morreu tão jovem". Simone falou: "eu não teria coragem de ler o atestado de óbito do meu pai não. Olga contou da carta enviada por sua mãe, que recebeu na unidade prisional três dias após sua morte: "eu fui no velório, chorei demais. Depois de três dias chegou a carta dela. Ela tinha escrito há mais tempo, mas demorou a chegar. Eu carreguei esta carta comigo no sutiã por muito tempo".

Em uma das unidades, quando coloquei o fone de ouvido, Hilda falou: "acho que sei que música você vai ouvir. É do Milton Nascimento?”. cantarolou um verso de Travessia. Falou: é a música que me lembra meu pai também. Falei então que ela ouviria a música antes de mim. Coloquei o fone nela, apertei o play. Ela fechou os olhos. Ouviu muito atenta e com grande emoção. Cantarolou baixinho, de olhos fechados e cantarolei com ela. A sala ficou em silêncio. Hilda chorou bastante ouvindo a música, ainda de olhos fechados. Sentei-me ao seu lado e queria ter segurado sua mão, mas decidi apenas me mostrar próxima. Em todas as unidades as mulheres quiseram escutar a música e o fone de ouvido passou por todas elas, que ouviram de modo solitário e compartilhado ao mesmo tempo.

A música, ouvida e dançada em público, mas na solidão do fone de ouvido, demarca uma ausência na presença, uma solidão que se vive em companhia. Música que simboliza o fim do luto e a reconciliação com a própria história, a criação de possibilidades de vida a partir da morte, mas que preserva, ainda, o silêncio e o vazio que ficam.

A composição começa em um lamento: "Quando você foi embora/Fez-se noite em meu viver/Forte eu sou mas não tem jeito/Hoje eu tenho que chorar". E vai, pouco a pouco, revelando um trajeto de restauração: "Vou seguindo pela vida/ Me esquecendo de você/Eu não quero mais a morte/ Tenho muito que viver". 
Apresentei-me performando um trabalho artístico significativo e existencial para abrir possibilidades de convívio.

Confesso que realizar a ação Travessia me provocava, sempre, certa ansiedade e frio na barriga: como seria desvelar questões tão pessoais para mulheres que viviam em condições muito mais duras e sofridas que a minha? Eu me lembrei, em todas as vezes, de Eleonora Fabião (2008, p. 14), para quem performar é como colocar propositalmente pedras no sapato:

um performer não apenas coloca propositalmente pedras em seu sapato mas usa sapatos de pedra para que outros fluxos e outras maneiras de percepção e relação possam circular.

As mulheres em todas as unidades me receberam de modo acolhedor e, quase sempre, num silêncio cúmplice. O trabalho parecia quebrar um pedaço de barreira simbólica que nos separava. Após vivê-la, nos olhávamos de modo mais tranquilo: nascia um pedaço de confiança que dava densidade ao convívio.

\section{Momentos 3 e 4: Criação e compartilhamento de cartas}

No terceiro dia propus que escrevessem também cartas para pessoas presentes ou ausentes em suas vidas, ou até mesmo inexistentes. Propus a criação de cartas como um modo de se apresentarem a mim, assim como eu me apresentei a elas e compartilhei aspectos de minha intimidade. A carta, que guarda afetos, era também uma forma de falar de si. Era ainda um modo de fazer teatro, performar: eu partia do princípio de que a criação e compartilhamento daquelas cartas seria mote para um encontro de intimidades e para um acontecimento teatral contemporâneo. Teatro fundado na convivialidade, numa zona intersticial difícil de ser definida.

Ofereci folhas, envelopes, selos, postagem nos correios - algo quase banal na nossa experiência cotidiana mas que, revelaram-me as mulheres presas, para algumas é um luxo: "vai me ajudar muito, porque tô sem receber pertence, tô sem poder mandar carta”. Alguém brincou: “vai fazer igual a Dora não né?”. E eu, de 
fato, brinquei de ser Dora: quem quis pôde ditar suas cartas para que eu escrevesse.

A leitura e escrita foi, muitas vezes, acompanhada de narrativas pessoais, depoimentos, dizeres que revelavam os sentidos daquelas cartas. O mote para o convívio foi a criação e partilha de cartas, mas o acontecimento vivido foi mais amplo, expandiu-se em diálogo. As cartas revelaram, sempre, algo sobre suas autoras e condições de vida. O ato de compartilhar provocou comoção. Como diria Conceição Evaristo, seus olhos d'água "se confundiam com os olhos da natureza. Chovia, chorava! Chorava, chovia”. Intento, aqui, partilhar e dizer desse encontro de intimidades (André, 2008); desvelar fragmentos dos mundos de vida das mulheres participantes, no modo como se apresentaram a mim.

A carta a meu pai matizou a escrita de outras cartas para pessoas ausentes: tentativa de juntar lembranças; sublimar a saudade. Olga escreveu para a mãe falecida. Uma resposta à carta que chegou à unidade três dias após o enterro. A carta, última presença da mãe, levada junto ao seio, me parece simbolizar a própria maternidade: em sua escrita, Olga agradece à mãe pelo leite que a alimentou e diz que, com sua morte, a vida a tornou a matriarca da família. Enviou a carta para si mesma em seu endereço residencial: "Aquela casa vazia [...]. Vai ajudar a "tocar a vida quando eu voltar".

Luíza também visitou a morte da mãe. A carta, enviada para a irmã, começa assim: "Palavras que eu queria dizer à minha mãe.". Ela fala das lembranças, como se falasse com a própria mãe. Luíza é séria, calada, parece guardar dentro de si um nó, uma dor. Escreveu: "Nesse lugar sombrio tudo que eu queria era seu abraço e carinho de mãe." Hilda, que escreveu para uma irmã, com lembranças sobre a morte de outra irmã, ao final do encontro me abraçou e agradeceu: "Obrigada por ter deixado eu compartilhar a morte da minha irmã com você.".

Na ida às prisões conheci muitas mães que choram a distância de seus filhos. Expressam preocupações quanto à vida lá fora. Às vezes, há a possibilidade de perder a guarda. Por vezes enviam conselhos preocupados a filhos envolvidos nos tortuosos caminhos da criminalidade. Pedem perdão. Sentem culpa ou vergonha. 
Choram a perda dos filhos. Temem o esquecimento. Algumas não recebem suas visitas porque são criados por pessoas que não têm a guarda legal e, portanto, não podem levá-los. Alguns filhos não sabem que a mãe está presa. Pensam que está trabalhando ou estudando fora. Outras vezes, nem isso: têm que lidar com uma ausência inexplicável. Alguns filhos também estão privados de liberdade em centros socioeducativos ou unidades prisionais.

Rosa, que escreveu para os dois filhos também presos, afirmou que abriria mão da sua liberdade pela deles. Virgínia tem um semblante triste, de gente do interior, envelhecido pelo tempo. É branca, muito magra, os cabelos escuros. Quis escrever para o Conselho Tutelar de sua cidade: ansiava por notícias do filho. Chorou enquanto me ditava a carta onde fala que o filho é sua vida. Agradeceu quem estivesse cuidando dele, mas disse: "Quando sair vou querer meu filho de volta.". Perguntei se tinha muito tempo que não tinha notícias dele e contou que havia um mês, mas para ela é uma eternidade. Estava preocupada: é ela quem paga todas as contas, havia o aluguel, além de R\$ 870,00 "para sair da prisão" (fiança). Falou que seu caso não é grave: "Sou usuária e fui pega fumando um baseado com um menor ${ }^{12}$."

Na carta que escreveu ao pai, ditada a mim, Maria pediu notícias de seus filhos. Contou-me que são três ao todo: "A Renatinha foi Deus quem me deu. Eu não sei quem é o pai. Fui estuprada, não me lembro, tava drogada”. Encontrei ecos da história de Maria em um conto de Conceição Evaristo (2015, p. 50), onde li sobre "um filho que fora concebido nos frágeis limites da vida e da morte."

Marta escreveu uma carta de perdão a si mesma se perdoando pelos erros e por não ter sido uma boa mãe - talvez por ter sofrido, ela também, a ausência de bons pais. Cantou uma música para a filha do meio - segundo ela: "Filho do meio é mais carente.". Confessei: "Sou filha do meio". Contou que quando essa filha nasceu, não tinha como ficar com ela, ia dar para os outros. Foi para o hospital

12 Poucos dias depois da residência, liguei no Conselho Tutelar para pedir o endereço e enviar a carta, pois não encontrei pela internet. Consegui falar com a pessoa para quem ela endereçou a carta. Soube então que Virgínia havia sido solta e perdeu a guarda do filho, que está com uma família acolhedora. A nova responsável pela criança teria dito que ela pode visitá-lo quando quiser. Disse ainda que Virgínia demorou a aceitar a decisão. E que se quiser ficar com filho, terá que se cuidar, parar de usar drogas. 
sem levar nem uma fralda, mas não queria dar a filha, já a amava. Quando o médico colocou no seu colo, pensou: "Não vou dar, ela vai passar fome junto comigo, mas vai ficar comigo." Cantou:

\author{
Clara como a luz do sol \\ Clareira luminosa nessa escuridão \\ Bela como a luz da lua \\ Estrela do oriente nesses mares do sul \\ Clareira azul no céu \\ Na paisagem \\ Será magia, miragem, milagre \\ Será mistério \\ Prateando horizontes \\ Brilham rios, fontes \\ Numa cascata de luz \\ No espelho dessas águas \\ Vejo a face luminosa do amor \\ As ondas vão e vem \\ E vão e são como o tempo \\ Luz do divinal querer \\ Seria uma sereia \\ Ou seria só \\ Delírio tropical, fantasia \\ Ou será um sonho de criança \\ Sob o sol da manhã. (Santos, 1995).
}

Marta contou que quem the salvou foram os filhos: se não existissem talvez ela já tivesse morrido. Inicialmente queria enviar a carta para si mesma na unidade. Depois, decidiu mandar para casa e endereçou aos filhos. No final da carta, em que perdoa a si mesma, escreveu: “Eu me perdoo. E vocês? Me perdoam?”. Depois de compartilhar, Marta escreveu uma carta em que perdoa a mãe, desaparecida em fevereiro de 2006. Ela acredita que um dia ainda irão se reencontrar. A carta foi endereçada a Deus e doada à pesquisa. Pedir o perdão dos filhos terá reverberado em Marta de modo a conseguir perdoar a mãe?

Violeta tem quatro filhos que não sabem que está presa e têm que lidar com uma ausência inexplicável. Ela pretendia escrever para as crianças, mas desistiu ao perceber que o endereço da penitenciária iria no envelope. As crianças já escreveram para ela, mas sua mãe não teve coragem de enviar: Violeta não suportaria. Foi também a mãe que disse que não havia nada mais triste do que 
quando escurece. As crianças falam: "será que hoje minha mãe volta?”.

Violeta tem medo de que seu caçula se esqueça dela, se esqueça de seu rosto. Outras mulheres também compartilharam o medo do esquecimento. Luíza contou que seu filho mais novo não a reconhece como mãe. As dores desse esquecimento me fazem evocar Dora. No filme, já no fim da viagem, ela conta uma história de sua vida para Josué, fala do reencontro com seu próprio pai, que não a reconheceu. Ela reclama a falta de uma foto:

eu também, às vezes, eu esqueço a cara do meu pai. Não devia ter a merda da fotografia, né? Pra gente não ter que lembrar. Podiam deixar a gente esquecer.

Essas experiências evidenciam, mais uma vez, o despojamento do papel: nesse caso, as mulheres presas perdem a possibilidade de serem mães de seus filhos. Segundo Goffman (2010, p. 25)

embora alguns dos papéis possam ser restabelecidos pelo internado, se e quando ele voltar para o mundo, é claro que outras perdas são irrecuperáveis e podem ser dolorosamente sentidas como tais. Pode não ser possível recuperar, em fase posterior do ciclo vital, o tempo não empregado no progresso educacional ou profissional, no namoro, na criação dos filhos.

O autor ressalta que, nem sempre se trata de perdas temporárias, em certos casos, pessoas presas "podem ter alguns desses direitos permanentemente negados", justamente pela impossibilidade de vivê-los e de situações em que o tempo é mesmo irrecuperável.

Mattos (2006) organizou algumas produções textuais de mulheres presas. Em um desses textos pude ler:

Há quinze dias atrás, recebi visita da minha mãe, juntamente com alguns amigos e minha filha que hoje tem 6 anos, a que eu deixei com apenas 10 meses. Já tinha 2 anos e 5 meses que eu não a via. Perguntei a ela se ela se lembrava de mim e ela disse que não. Tive que ser muito forte para não chorar ou gritar ali mesmo. (Mattos, 2006, p. 103).

Goffman (2010, p. 64) afirma que o sentimento de que o tempo na privação de liberdade é um tempo perdido, "tirado da vida da pessoa", é comum a muitos 
internos; a prisão constitui, nesse caso, um exílio da vida, como escreveu uma mulher presa (Mattos, 2006): "É como se todo mundo estivesse órfão da vida...".

Por vezes, nos dizeres (ou não dizeres) das mulheres presas, senti o desamparo no olhar, no silêncio, nas palavras que saíam em fluxo descontrolado ou lentamente, quase com dificuldade.

Margarida tem uma postura bem amuada, humilde, calada. Ao ditar sua carta, para a mãe, teve muita dificuldade. Em vários momentos me disse: "Eu não sei falar.". Eu the disse que a carta é como se a gente estivesse falando com a pessoa, então era só ela dizer o que queria falar com a mãe. Disse: "Fala pra ela que eu tô com muita saudade, que mandei um abraço pra ela e um feliz aniversário... E muito beijos.”. Perguntei: “Tem mais alguma coisa que você gostaria de dizer a sua mãe?”. Disse que sim. E eu: “O quê?”. Ela: “Eu não sei falar... Já falou do aniversário?”. Perguntei se queria dizer de sua vida lá. Respondeu que sim: "Aqui é muito sofrimento".

Leila, uma jovem de 21 anos que emagreceu 16kg na prisão, me ditou, em carta escrita ao tio: "por favor, diz pra minha irmã não me abandonar aqui, porque aqui é escuro". Contou da visita da filha, de 6 anos, que quis ir logo embora e confessou: "eu tô me sentido presa". Quem disse isso foi a filha, mas foi também Leila, como quem revelasse: "eu não consigo respirar". Falava de um jeito desolado, de quem sofria. Emanava um desespero.

Algumas cartas também evidenciavam o abandono e a solidão em que viviam suas autoras, como quando Francisca escreveu para a mãe: "eu gostaria de receber visita, mas ninguém pode vim (sic) me ver, eu entendo". Célia também escreveu para a mãe: "Entendo porque não me visita, a vida aí fora não tá fácil.". Ou Dandara: "não quero que me visite, mas peço que me envie pelo menos uma carta com seu número de telefone novo, porque não tenho".

Nadir escreveu para o marido, também preso: "até o dia de hoje não the escrevi, pois não tive como arrumar tarifado, então agora está tendo essa oportunidade de uma visita na ala em que a senhora vai enviar a carta”. Ela também me disse: "você não sabe o bem que fez, a carta é uma visita". 


\section{A carta, uma visita}

A potência de um trabalho com cartas na espacialidade prisional superou minhas expectativas e compreensões quando da construção da proposta. Inicialmente, tive dúvidas se o trabalho seria realmente significativo para as mulheres presas. Como principal modo de comunicação entre elas e o mundo exterior, escrever cartas talvez fosse algo tão comum em seus cotidianos que a proposta poderia soar como "desnecessária”. Mas ao viver o encontro com elas, vi as dificuldades de envio e a espera cotidiana por cartas que não chegam. Descobri que a importância das cartas para aquelas mulheres situava-se para muito além da comunicação, estando mais próximo do que Goffman (2010) nomeou "abrigo do eu". Entendo, então, que, diante dos processos de mortificação vividos nas unidades prisionais, o espaço da residência artística propiciou abrigos temporários e coletivos para o eu.

Afinada com práticas contemporâneas, busquei construir uma proposta aberta na qual investi na possibilidade e potência do encontro; proposta atravessada por riscos e incertezas, pelo acaso e imprevisível, pelo imponderável da vida. Parti de uma ideia cujo fundamento é relacional e autobiográfico, encontra-se em um limiar que dificulta distinguir e separar vida e arte:

o teatro, assim como as outras artes, não deveria temer a intervenção de realidades extra-teatrais. Para evoluir e ser vivo, o teatro deve sair de si mesmo - deixar de ser um teatro. (Kantor apud Caballero, 2011, p. 108).

Apresentei-me às mulheres presas através da morte, do luto e da solidão. A leitura do atestado de óbito seguida pela carta e música, de alguma forma ritualiza a morte para em seguida transcendê-la. O trabalho expôs meus laços familiares a mulheres que vivem situações dolorosas: a saudade, a ausência, sentimentos de culpa, o abandono. É possível relacioná-lo à ideia apresentada por Carlson (2010), acerca da "perspectiva de fornecer um corpo e uma voz para a experiência comum" (p. 133) - a experiência da morte, da ausência, da solidão; algo que 
culminou em um processo de apropriação quando as mulheres presas revelaram suas próprias experiências de luto, vida e morte.

Caballero (2011, p. 74) comenta experiências teatrais que criam uma communitas xamânica ao propiciarem "um caminho de restaurações simbólicas". A autora refere-se a xamânico num sentido curativo, sem as conotações religiosas que comumente são associadas ao termo. Em trabalhos que possuem uma dimensão xamânica "as ações poéticas parecem ajudar a regeneração do tecido da memória para que as comunidades e as pessoas possam começar a ultrapassar a dor."

De acordo com o pensamento de Dubatti a poíesis é entendida como morada habitável, propõe e configura outros modos de organizar a realidade e habitar o mundo e revela outros espaços existenciais:

fugir das pressões, para inventar outras territorialidades de subjetividade e regressar com nova força: a poíesis, trajeto de criação e obra criada, como uma máquina de ar em um mundo irrespirável (Dubatti, 2007, p. 168).

O espaço prisional pode ser tomado como esse mundo irrespirável. Leila, em seu desabafo (p. 106-107) me passou mesmo a impressão de que the faltava o ar. No livro de Mattos (2006, p. 114), que reuniu produções textuais de mulheres presas, pude ler:

estar presa é uma das piores experiências que uma pessoa pode ter. Quando o carcereiro bate a porta e fecha a tranca, toda esperança foge do coração, um sentimento ruim começa a sufocar até o mais valente.

$\mathrm{Na}$ pesquisa, pudemos, no acontecimento poético, habitar nossas próprias dores, solidão, medos, saudade. A proposta foi criada a partir das "relações ambíguas entre drama da vida e elaboração artística [...] entre espaços do real e os espaços artísticos" (Caballero, 2011, p. 118). Parece haver algo de curativo naquele processo de escrever cartas para pessoas ausentes ou presentes em suas vidas, falar da morte, fazer inventários de lembranças, pedir perdão, se perdoar, perdoar o outro, ouvir e ser ouvida, olhar e ser olhada. 
A partir dessa perspectiva, a concepção da poíesis como morada encontra ressonância na própria ideia da residência artística: através da proposta, encontrei modos de habitar o espaço prisional. Criamos - eu e as mulheres participantes essas moradas habitáveis, efêmeras: uma espécie de pouso, ninho, estada, abrigo.

Propus a residência artística como possibilidade de criação de antiestruturas: respiros, ranhuras na cotidianeidade normatizada e normatizadora das unidades prisionais. Na obra de Turner (2012), antiestrutura corresponde à ideia de liminaridade e communitas - são conceitos "irmãos" que carregam os mesmos sentidos. Na construção dessa noção, Turner cita Sutton-Smith, para quem "a estrutura normativa representa o equilíbrio, a 'antiestrutura' representa o sistema latente das alternativas potenciais." (Sutton-Smith apud Turner, 2012, p. 223).

Turner (2012, p. 36) me soa provocativo ao indagar: "então o que é communitas? Isso tem uma base real ou é uma fantasia persistente do ser humano, um tipo de retorno coletivo ao útero?”. Não é à toa que Caballero (2011) refere-se à communitas como a possibilidade que funda "utopias de proximidade".

Turner (1974, p. 169) afirma que

o tipo de "communitas" desejado [...] não é a camaradagem aprazível e sem esforço, que pode surgir entre amigos, colaboradores e colegas de profissão, em qualquer tempo. O que buscam é uma experiência transformadora, que vai até as raízes do ser de cada pessoa, e encontra nessas raízes algo profundamente comunal e compartilhado.

Há algo mágico na experiência da communitas: ela acontece no "modo subjuntivo da cultura, o modo do 'talvez', do 'pode ser', do 'como se', hipótese, fantasia, conjectura, desejo" (Turner, 2005, p. 183). Já a vida cotidiana opera no modo indicativo, da racionalidade. Avento que, no âmbito desta pesquisa, vivemos experiências de communitas. Acredito que experimentamos o

fugaz estado de êxtase e sentido de união (com duração frequente de somente alguns segundos) [que] pode ser descrito como um arrepio nada mais que isso - que desce pelas costas até um certo ponto (D’Aquili e Laughlin apudTurner, 2005, p. 185). 
Mais de uma vez ouvi as mulheres participantes dizerem que receber uma carta é como receber uma visita. Isso dito por quem vive a solidão da privação de liberdade, algumas vezes, em situação de abandono.

Durante nossos encontros, elas escreveram cartas de saudade e de pedido de perdão, para pessoas presentes e ausentes, para suas mães, pais e filhos, para companheiros e ex-companheiros. Cartas para si mesmas, para Deus, para mim. Carta para a filha ainda bebê, que poderá ler quando crescer. Cartas enviadas para si mesmas, nos seus endereços residenciais, para lerem quando, em liberdade, chegarem em casa.

Construímos, juntas, um espaço de acolhimento, para mim e para elas. Criamos relações horizontais. As mulheres participantes, com quem teci redes de afeto e humanidade, agradeceram a presença, algumas vezes se emocionaram ao dizer dos preconceitos que sofrem. Disseram-me, através da escrita das cartas para familiares: aqui é escuro, aqui é sombrio. Falaram de humilhação.

Parti do princípio de que o teatro é feito de convívio e presença e a escrita e compartilhamento de cartas, ficcionais ou biográficas, foi, como esperado, mote para um acontecimento teatral contemporâneo. A participação das mulheres presas na residência artística propiciou um lugar de diálogo, bem como de expressão e reconhecimento de si: encontro de intimidades (André, 2008). Lugar de acolhimento, afeto, humanidade e presença no espaço prisional, ambiente escuro, sombrio, que preza pela obediência e disciplina: brechas que se revelam possíveis através das artes da cena.

Busquei modos radicais de pensar e fazer teatro em companhia de mulheres presas. A sensação é ambígua: por um lado sinto-me impotente diante de um sistema que desumaniza tantas vidas. Por outro, afirmo a potência dos acontecimentos teatrais em situações liminares, a criação poética compartilhada em encontros de intimidades. Momentos-faíscas: pequenos, porém potentes ciscos de luz que iluminam a experiência.

É Clarice Lispector (2012, p. 112), em conto sobre a morte de Mineirinho, assassinado com treze tiros, quem diz: 
Essa justiça que vela meu sono, eu a repudio, humilhada por precisar dela. Enquanto isso durmo e falsamente me salvo. Nós, os sonsos essenciais. Para que minha casa funcione, exijo de mim como primeiro dever que eu seja sonsa, que eu não exerça a minha revolta e o meu amor, guardados. Se eu não for sonsa, minha casa estremece. Eu devo ter esquecido que embaixo da casa está o terreno, o chão onde nova casa poderia ser erguida.

A autora afirma "eu não quero esta casa” (2012, p. 113). E completa:

Não, não é que eu queria o sublime, nem as coisas que foram se tornando as palavras que me fazem dormir tranquila, mistura de perdão, de caridade vaga, nós que nos refugiamos no abstrato. O que eu quero é muito mais áspero e mais difícil: quero o terreno. (Lispector, 2012, p. 115).

Parece-me que o teatro, esse desejo um tanto utópico que me move, instaurou no espaço prisional um terreno outro, ainda que efêmero, imediato, momento fugaz: segundos, talvez, dos quais permanece o arrepio.

\section{Referências}

ANDRÉ, Carminda Mendes. Espaço inventado: o teatro pós-dramático na escola. Educ. rev., Belo Horizonte, n. 48, p. 125-141, Dec. 2008. Disponível em http://www.scielo.br/pdf/edur/n48/a07n48.pdf

BRANT, Fernando; NASCIMENTO, Milton. Intérprete: Milton Nascimento. Travessia. Álbum: Travessia. Gravadora: Ritmos-Codil (LP)/Dubas Música (CD). 1967.

CABALLERO, Ileana Diéguez. Cenários liminares: teatralidades, performances e política. Tradução: Luis Alberto Alonso e Angela Reis. Uberlândia: EDUFU, 2011.

CARLSON, Marvin. Performance: uma introdução crítica. Tradução: Thaís Flores Nogueira Diniz; Maria Antonieta Pereira. Belo Horizonte: Editora UFMG, 2010.

Central do Brasil. Direção: Walter Salles. Roteiro: João Emanuel Carneiro, Marcos Bernstein. Produção: Elisa Tolomelli. Brasil; França; 1998. 1 DVD. 112 min.

CONCÍLIO, Vicente. Teatro e Prisão: dilemas da liberdade artística. São Paulo: Aderaldo \& Rothschild, 2008. 
DUBATTI, Jorge. Filosofía del teatro T. convivio, experiencia, subjetividad. Buenos Aires: Atuel, 2007.

EVARISTO, Conceição. Olhos d'água. Rio de Janeiro: Pallas: Fundação Biblioteca Nacional, 2015.

FABIÃO, Eleonora. Performance e teatro: poéticas e políticas da cena contemporânea. Sala Preta, Brasil, v. 8, p. 235-246, nov. 2008. Disponível em: <http://www.revistas.usp.br/salapreta/article/view/57373>. Acesso em: 13 maio 015.

FOUCAULT, Michel. Vigiar e Punir. nascimento da prisão. Tradução: Raquel Ramalhete. Petrópolis, RJ: Vozes, 2010.

GOFFMAN, Erving. Manicômios, prisões e conventos. São Paulo: Perspectiva, 2010.

HISSA, Cássio Eduardo Viana. Entrenotas: compreensões de pesquisa. Belo Horizonte: Editora UFMG, 2013.

LISPECTOR, Clarice. Mineirinho. In: NUNES, Aparecida Maria (orgs). Clarice na cabeceira: jornalismo. Rio de Janeiro: Rocco, 2012.

MACHADO, Marina Marcondes. Só Rodapés: Um glossário de trinta termos definidos na espiral de minha poética própria. Revista Rascunhos / Caminhos da pesquisa em artes cênicas. Uberlândia, UFU. v. 2, n. 1 (2015): Dossiê Teatro e Escola: ações e reflexões.

MARTINS, Joel. Uma abordagem de currículo na perspectiva fenomenológica. In: MARTINS, Joel. Um enfoque fenomenológico do currículo: educação como poíesis. São Paulo: Cortez, 1992.

MATTOS, Virgílio de; PINTO, João Batista Moreira (orgs). A legibilidade do ilegível: textos produzidos por mulheres condenadas e em cumprimento de pena privativa de liberdade, no início do século XXI, em Belo Horizonte. Belo Horizonte: Fundação MDC, 2006.

MELO, Luciana Cezário Milagres de. Mergulho no Escuro: O teatro é [no] encontro com o outro no mundo. 2017. Dissertação (Mestrado em Artes) - Escola de Belas Artes - Universidade Federal de Minas Gerais, Belo Horizonte, 2017.

MORAES, Marcos. Residência artística: ambientes de formação, criação e difusão. 2009. Tese (Doutorado em Arquitetura e Urbanismo). Faculdade de Arquitetura e Urbanismo, Universidade de São Paulo, São Paulo, 2009. Disponível em: http://biblioteca.posgraduacaoredentor.com.br/link/?id=2363996. Acesso em: 28 dez. 2016.

PACKER, Amilcar. Resiliências artísticas. In: BEZERRA, André; VASCONCELLOS, Ana 
(org.). Mapeamento de residências artísticas no Brasil. Rio de Janeiro: Funarte, 2014. Disponivel em: http://www.funarte.gov.br/residenciasartisticas/wpcontent/uploads/2014/07/miolo+capa-Livro-res-artisticas-FINAL_baixa-res.pdf. Acesso em: 28 dez. 2016.

QUEIROZ, Nana. Presos que menstruam. Rio de Janeiro: Record, 2015.

SANTOS, Lulu. Sereia. Álbum: Eu e Memê, Memê e Eu. 1995

STRECKER, Marcos. Na estrada: o cinema de Walter Salles. São Paulo: Publifolha, 2010.

TURNER, Victor W. O processo ritual: estrutura e anti-estrutura. Tradução: Nancy Campi de Castro. Petrópolis, Vozes, 1974.

TURNER, Victor. Dewey, Dilthey e Drama: um ensaio em Antropologia da Experiência (primeira parte). Tradução: Herbert Rodrigues. Cadernos de Campo, São Paulo, v. 13, n. 13, p. 177-185, 2005. Disponível em: http://www.revistas.usp.br/cadernosdecampo/article/view/50265. Acesso em: 10 jan. 2017.

TURNER, Victor. Liminal ao liminoide:em brincadeira, fluxo e ritual. Um ensaio de simbologia comparativa. Tradução: Herbert Rodrigues. Mediações, Londrina, v. 17, n.2, $\quad$ p. 214-257, 2012. Disponível em: http://www.uel.br/revistas/uel/index.php/mediacoes/article/view/14343. Acesso em: 10 jan. 2017.

VASCONCELOS, Ana. Apontamentos para a construção de um programa Funarte de residências artísticas. In: BEZERRA, André; VASCONCELLOS, Ana (org.). Mapeamento de residências artísticas no Brasil. Rio de Janeiro: Funarte, 2014. Disponível em: http://www.funarte.gov.br/residenciasartisticas/wpcontent/uploads/2014/07/miolo+capa-livro-res-artisticas-FINAL_baixa-res.pdf. Acesso em: 28 dez. 2016.

Recebido em: 15/10/2020

Aprovado em: 11/12/2020 